\title{
SENSITIVITY OF STAPHYLOCOCCI TO FATTY ACIDS: NOVEL INACTIVATION OF LINOLENIC ACID BY SERUM
}

\author{
R. W. LACEY AND Vicki L. LORD \\ Department of Bacteriology, North Cambridgeshire Hospital, Wisbech, Cambridgeshire
}

\begin{abstract}
SUMmaRY. The inhibition of coagulase-negative staphylococci and Staphylococcus aureus of human or animal origin by most free fatty acids was similar, but coagulase-positive staphylococci were sensitive and coagulase-negative cultures were resistant to linolenic acid. Animal strains of $S$. aureus were more sensitive to linolenic acid than were human strains. These differences were reflected in the relative abilities of the three categories of strains to survive on human skin.

The antibacterial effects of $20 \mathrm{mg}$ of linolenic acid were inactivated by $1 \mathrm{ml}$ of serum in vitro. A test organism seeded on to skin also survived better if first suspended in serum. The mechanism of the interaction between serum and linolenic acid may be due to a detergent effect of the serum and could account for colonisation of diseased skin with $S$. aureus.

Cultures of $S$. aureus seeded on to human skin were rapidly killed after the skin has been covered with linolenic acid. The possibility of therapeutic use of linolenic acid as an antibacterial agent should be explored.
\end{abstract}

\section{INTRODUCTION}

Factors that may contribute to the elimination of bacteria from intact human skin are desiccation, low $p \mathrm{H}$, the presence of free fatty acids (Ricketts, Squire and Topley, 1951; Lacey, 1968; Aly et al., 1976), the production of antibiotics by the resident commensal flora (Selwyn and Ellis, 1972) and shedding of squames by abrasion. However, it is not known why Staphylococcus epidermidis and some related species are often present in normal skin whereas $S$. aureus is infrequently found (Lacey et al., 1980). It is also not clear why $S$. aureus can often be isolated from skin damaged, for example, by eczema or psoriasis, or why strains of $S$. aureus from animal sources rarely colonise man.

One of the properties of cutaneous fatty acids thought to be responsible for their antibacterial activity is their degree of unsaturation. The inhibitory capacity might increase with the degree of unsaturation so that linolenic acid (which contains three double bonds) is the most inhibitory, linoleic (two double bonds) less so, with oleic (one double bond) and stearic (saturated) with 
insignificant antibacterial properties (Butcher, King and Dyke, 1976; Ko, Heczko and Pulverer, 1978; Heczko, et al., 1979). However, linoleic acid can be more inhibitory to bacteria than linolenic (Bayliss, 1936; Fuller and Moore, 1967; Kabara et al. (1972). The amount of free linoleic acid in normal skin exceeds that of linolenic acid (Wilkinson, 1972) so the precise significance of the presence of these and other acids is not clear.

This paper reports on the relative sensitivities of coagulase-negative staphylococci, and coagulase-positive staphylococci from human and animal sources, to various fatty acids, and we also describe a novel serum activity that destroys the antibacterial effect of linolenic acid.

\section{MATERIALS AND METHODS}

Bacteria. Two hundred and sixteen strains of $S$. aureus were from a variety of animals (Lacey, 1980a), 156 strains were from infected patients at Wisbech and King's Lynn from 1975 to 1979, 49 from the Division of Hospital Infection, Central Public Health Laboratory, Colindale and 33 from the State Serum Institute, Copenhagen. Cultures were thrice purified and stored without subculture on agar slopes at room temperature. One hundred and five cultures of coagulase-negative staphylococci were obtained from the surface of forearm skin of six patients and 10 healthy laboratory staff and were allocated by the API method (API Staph., lot no. HDO-04E) (Kloos and Schleifer, 1975) into the following species: $S$. epidermidis (48 strains), $S$. haemolyticus (5), S. haemolyticus II (14), S. capitis (10), S. warneri (3), S. hominis (1), S. saphrophyticus (2). S. cohnni (2) and unclassifiable (20).

Chemicals. Free fatty acids were the most purified grade available from Sigma. Purified human albumin was obtained from the Blood Products Laboratory, Elstree and contained 160 mmol Na/L. Unless otherwise stated "serum" refers to a pool obtained from about 100 human donors.

Determination of sensitivity to fatty acids. Free fatty acids that were oils at $56^{\circ} \mathrm{C}$ were incorporated into molten Blood Agar Base (Oxoid) to final concentrations of $1 \cdot 0,0 \cdot 5,0 \cdot 25,0 \cdot 1$, $0.05,0.025,0.01$ and $0.005 \%(\mathrm{v} / \mathrm{v})$. Stearic and palmitic acid were dissolved in $74 \%(\mathrm{v} / \mathrm{v})$ alcohol before addition to molten agar at $56^{\circ} \mathrm{C}$. The agar was then shaken for $\sim 20 \mathrm{sec}$. and cooled under running cold water with rotation until the temperature was $\sim 40^{\circ} \mathrm{C}$. Of the resultant emulsions, $20 \mathrm{ml}$ was poured into $9-\mathrm{cm}$ petri dishes. The plates were dried for $3 \mathrm{~h}$ at $37^{\circ} \mathrm{C}$ and then inoculated with cultures diluted sufficiently to give isolated colonies. The end point (MIC) was defined as the concentration of fatty acid required to inhibit the growth of $95 \%$ of the inoculated cocci after incubation at $37^{\circ} \mathrm{C}$ for $24 \mathrm{~h}$.

Survival of staphylococci on the skin. All the test organisms were first "marked" by a selection for mutants resistant to rifampicin, and the media for viable counts of the original inoculum and the bacteria recovered from the skin contained rifampicin $100 \mu \mathrm{g} / \mathrm{ml}$. Overnight broth cultures of each test culture were centrifuged, resuspended in physiological saline and then diluted 1 in 100 with physiological saline or serum, and $10-\mu \mathrm{L}$ portions were spread over $44 \mathrm{~mm}$ diameter circular areas of unprepared skin on the forearms of healthy volunteers. Subjects were asked not to use antibacterial soap during the course of the experiments. The inoculated arms were immediately covered by a loose polyethylene tube fastened by elastic bands at the elbow and wrist. The volunteers continued normal technical activities for $6 \mathrm{~h}$ then each inoculated area was sampled: a plastic ring was firmly placed in contact with the skin, $1.0 \mathrm{ml}$ of physiological saline was pipetted into the ring and the area was vigorously irrigated with a pipette for $30 \mathrm{~s}$. The fluid was withdrawn and viable counts obtained after further dilution in physiological saline. Preliminary experiments showed that $\sim 50 \%$ of the inoculum was lost during the initial application of the culture. Twelve replicates gave a coefficient of variation of $63 \%$. A control, uninoculated area on each arm was sampled to exclude the possibility of pre-existing rifampicinresistant $S$. aureus and coagulase-negative staphylococci. In some experiments $10 \mu \mathrm{L}$ of pure linolenic acid was spread over each test area immediately before the application of $c .10^{6}$ bacteria 
suspended in $10 \mu \mathrm{L}$ of serum. For these experiments the recovery and dilution fluid contained $0.01 \mathrm{M}$ calcium chloride to inactivate the antibacterial effects of linolenic acid. A proportion $(2 \%)$ of cultures of $S$. aureus recovered from the skin was checked for identity by bacteriophage typing.

Culture media, mutagenesis with nitrosoguanidine, and bacteriophage typing have been described previously (Lacey and Stokes, 1979).

Interaction between linolenic acid and serum. Linolenic acid was dissolved in $74 \%(\mathrm{v} / \mathrm{v})$ ethanol and added either to nutrient agar (Mast) or to distilled water containing $1 \%(\mathrm{v} / \mathrm{v})$ pure agar, $p \mathrm{H} 6 \cdot 0$. Serum or its components $(100 \mu \mathrm{L})$ were diluted in physiological saline and replicates were placed in randomly allocated $9-\mathrm{mm}$ wells. The resultant clearing of the fatty-acid emulsion around each well was measured after incubation for $20 \mathrm{~h}$ at $30^{\circ} \mathrm{C}$, unless otherwise stated.

\section{RESULTS}

Sensitivity of staphylococci to fatty acids

Initially, six strains of $S$. aureus of human origin (from non-hospitalised patients), six of animal origin (four cattle, two poultry) and six coagulase-negative staphylococci were tested for sensitivity to several fatty acids, excluding linoleic and linolenic acids. Little difference in the susceptibility of different strains was seen, but there were considerable differences in bactericidal potency among the different fatty acids (table I).

\section{Sensitivity of staphylococci to linoleic and linolenic acids}

Some variation in the inhibitory capacities of fatty-acid emulsions prepared on different occasions might be anticipated. This was assessed by tabulating the end point obtained on 20 different days for two reference strains, 1030 and 1030(55) (Lacey, 1980b). For linolenic acid, the median MIC for

\section{TABLE I}

Sensitivity of coagulase-negative staphylococci and Staphylococcus aureus from human and animal sources to fatty acids

\begin{tabular}{|c|c|c|c|}
\hline \multirow[b]{2}{*}{$\begin{array}{c}\text { Fatty acid } \\
\text { (number of carbon } \\
\text { atoms:double bonds) }\end{array}$} & \multicolumn{3}{|c|}{ Mean MIC $(\% \mathrm{v} / \mathrm{v})$ against } \\
\hline & $\begin{array}{l}\text { coagulase-negative } \\
\text { staphylococci } \\
\text { (6 strains)* }\end{array}$ & $\begin{array}{l}\text { S. aureus } \\
\text { (6 human } \\
\text { strains) }\end{array}$ & $\begin{array}{c}\text { S. aureus } \\
\text { (6 animal } \\
\text { strains) }\end{array}$ \\
\hline $\begin{array}{l}\text { Capric }\left(C_{10: 0}\right) \\
\text { Lauric }\left(C_{12: 0}\right) \\
\text { Myristic }\left(C_{14: 0}\right) \\
\text { Palmitic }\left(C_{16: 0}\right) \\
\text { Stearic }\left(C_{18: 0}\right) \\
\text { Oleic }\left(C_{18: 1}\right) \\
\text { Elaidic }\left(C_{18: 1}\right) \\
\text { Linoelaidic }\left(C_{18: 2}\right) \\
\text { Arachidonic }\left(C_{20: 4}\right)\end{array}$ & $\begin{array}{c}0 \cdot 1 \\
0 \cdot 1 \\
0 \cdot 05-0 \cdot 1 \\
1 \cdot 0 \\
0 \cdot 5 \\
>1 \cdot 0 \\
1.0 \\
1.0 \\
0.25\end{array}$ & $\begin{array}{c}0 \cdot 1 \\
0 \cdot 1 \\
0 \cdot 1-0 \cdot 5 \\
2 \cdot 5 \\
0 \cdot 5 \\
>1 \cdot 0 \\
1.0 \\
1 \cdot 0 \\
0.01-0.25\end{array}$ & $\begin{array}{c}0 \cdot 1 \\
0 \cdot 1 \\
0 \cdot 1-0 \cdot 5 \\
2 \cdot 5 \\
0 \cdot 5 \\
>1 \cdot 0 \\
1 \cdot 0 \\
1 \cdot 0 \\
0 \cdot 01-0.25\end{array}$ \\
\hline
\end{tabular}

* Three were $S$. epidermidis and three $S$. haemolyticus. 
both strains was $0.025 \%(\mathrm{v} / \mathrm{v})$ with a range from 0.01 to $0.05 \%$. For linoleic acid the median was 0.5 with a range $0 \cdot 1-1 \cdot 0 \%$. About $60 \%$ of each of the end points were at the medians. Because linolenic acid decomposes in aqueous emulsions (Gutteridge, Lamport and Dormandy, 1976), some experiments were performed in which a $10 \%(\mathrm{v} / \mathrm{v})$ emulsion of linolenic acid in physiological saline was incubated with agitation for $72 \mathrm{~h}$ at $37^{\circ} \mathrm{C}$ at $150 \mathrm{rpm}$ before inclusion into nutrient agar. The antibacterial activity as judged by 18 test bacteria (see above) was the same as that for medium containing freshly incorporated linolenic acid.

The sensitivity of a large number of staphylococci to free linolenic acid was measured. Most coagulase-negative staphylococci were at least 50 times more resistant than $S$. aureus of human origin, and these, in turn, were slightly more resistant than $S$. aureus strains from animals (table II). Of the 14 coagulasenegative staphylococci inhibited by $\leqslant 1.0 \%$ (v/v) linolenic acid, eight were $S$. capitis. Although the coagulase-negative staphylococci were resistant to linoleic acid, the sensitivity of $S$. aureus was variable, regardless of source (table II). Furthermore, eight $(36 \%)$ strains of $S$. aureus showed the phenomenon that some lower concentrations of acid (e.g., $0.05 \% \mathrm{v} / \mathrm{v}$ ) were inhibitory, but higher concentrations (e.g., $0 \cdot 1 \% \mathrm{v} / \mathrm{v})$ permitted growth over a narrow range. Such an effect was seen reproducibly in replicate experiments on different occasions for all these eight strains. The end points in table II are the concentrations of linoleic acid finally inhibiting growth.

TABLE II

Sensitivity of coagulase-negative staphylococci and Staphylococcus aureus from human and animal sources to linolenic and linoleic acids

\begin{tabular}{|c|c|c|c|c|}
\hline \multirow[b]{2}{*}{$\begin{array}{l}\text { Fatty } \\
\text { acid }\end{array}$} & \multirow[b]{2}{*}{$\operatorname{MIC}(\% \mathrm{v} / \mathrm{v})$} & \multicolumn{3}{|c|}{ Number of strains with stated MIC among } \\
\hline & & $\begin{array}{l}\text { coagulase-negative } \\
\text { staphylococcl } \\
\text { (105 strains) }\end{array}$ & $\begin{array}{l}\text { S. aureus } \\
\text { (238 human } \\
\text { strains) }\end{array}$ & $\begin{array}{c}\text { S. aureus } \\
\text { (216 animal } \\
\text { strains) }\end{array}$ \\
\hline Linolenic & $\begin{array}{l}0.005 \\
0.01 \\
0.025 \\
0.05 \\
0.1 \\
0.25 \\
0.5 \\
1.0 \\
>1.0\end{array}$ & $\begin{array}{r}0 \\
0 \\
0 \\
0 \\
0 \\
1 \\
1 \\
12 \\
91\end{array}$ & $\begin{array}{r}0 \\
6 \\
185 \\
47 \\
0 \\
0 \\
0 \\
0 \\
0\end{array}$ & $\begin{array}{r}16 \\
80 \\
98 \\
22 \\
0 \\
0 \\
0 \\
0 \\
0\end{array}$ \\
\hline Linoleic & $\begin{array}{l}0.01 \\
0.025 \\
0.05 \\
0.1 \\
0.25 \\
0.5 \\
>0.5\end{array}$ & $\begin{array}{r}0 \\
2 \\
0 \\
0 \\
0 \\
0 \\
103\end{array}$ & $\begin{array}{r}0 \\
35 \\
9 \\
19 \\
85 \\
17 \\
73\end{array}$ & $\begin{array}{r}1 \\
54 \\
4 \\
38 \\
5 \\
113 \\
1\end{array}$ \\
\hline
\end{tabular}


Survival of staphylococci on human skin

There were considerable but reproducible differences in the survival of individual strains in different volunteers, but within each group of strains the levels of survival were fairly consistent with respect to each volunteer. $S$. aureus strains of animal origin on average survived poorly compared with $S$. aureus strains from humans, and these in turn were poor survivors compared with the coagulase-negative staphylococci (see table III). Thus, the relative levels of survival of these groups of strains resembled their relative resistances to linolenic acid.

Rifampicin-resistant strains of $S$. aureus were recovered from the uninoculated area on only one subject on two occasions. They were identical in typing pattern to a culture seeded on the arm 4 days previously.

\section{TABLE III}

Survival of coagulase-negative staphylococci and Staphylococcus aureus from human and animal sources on the forearm skin of volunteers

\begin{tabular}{lc|cc}
\hline \multicolumn{1}{c|}{$\begin{array}{c}\text { Staphylococci } \\
\text { (origin) }\end{array}$} & $\begin{array}{c}\text { Number } \\
\text { of strains } \\
\text { tested }\end{array}$ & $\begin{array}{c}\text { Number of } \\
\text { experiments } \\
\text { (volunteers) }\end{array}$ & $\begin{array}{c}\text { Percentage of } \\
\text { inoculum } \\
\text { recovered } \\
\text { at } 6 \mathrm{~h} \\
\text { (range) }\end{array}$ \\
\hline $\begin{array}{l}\text { Coagulase-negative } \\
\text { (healthy human skin) }\end{array}$ & 11 & $44(6)$ & $\begin{array}{c}72 \cdot 0 \\
(7 \cdot 0-750)\end{array}$ \\
$\begin{array}{l}\text { S. aureus } \\
\text { (skin lesions of } \\
\text { non-hospitalised patients) }\end{array}$ & 6 & $36(6)$ & $\begin{array}{c}6 \cdot 2 \\
(0 \cdot 2-18 \cdot 0)\end{array}$ \\
$\begin{array}{l}S . \text { aureus } \\
\text { (animal: cattle 11 strains, } \\
\text { pigs 3, poultry 2) }\end{array}$ & 16 & $52(6)$ & $\begin{array}{c}0 \cdot 1 \\
(0 \cdot 01-28 \cdot 0)\end{array}$ \\
\hline
\end{tabular}

Effect of suspension in serum on survival of S. aureus on human skin

The effect of serum on the survival of the animal strain of $S$. aureus (CIX 76) was studied in six volunteers. Apart from one subject (no. 2) whose skin was highly bactericidal in the presence of saline or serum, suspension of the test organism in serum markedly increased the survival of the test culture (table IV).

\section{Interaction between serum and linolenic acid}

This was studied by incorporating pooled serum $1 \%(\mathrm{v} / \mathrm{v})$ linolenic-acid emulsion $0.01-1.0 \%(\mathrm{v} / \mathrm{v})$ into nutrient agar and noting the effect on the MIC of the 18 test staphylococci (see above). All the bacteria became more resistant to linolenic acid in the presence of serum so that $1 \mathrm{ml}$ of serum neutralised the antibacterial effect of $20 \mathrm{mg}$ of linolenic acid. 
TABLE IV

Effect of serum on the survival of Staphylococcus aureus (strain CIX76) on human skin

\begin{tabular}{c|cc}
\hline & \multicolumn{2}{c}{$\begin{array}{c}\text { Percentage }{ }^{*} \text { of inoculum } \dagger \\
\text { recovered from skin after } \\
6 \mathrm{~h} \text { suspended in }\end{array}$} \\
$\begin{array}{c}\text { Subject } \\
\text { no. }\end{array}$ & serum & saline \\
\hline 1 & 36.0 & 0.62 \\
2 & 0.06 & 0.05 \\
3 & 71.0 & 0.02 \\
4 & 88.0 & 0.06 \\
5 & 2.5 & 0.4 \\
6 & 10.0 & 0.07 \\
\hline
\end{tabular}

* Mean of three experiments. $\dagger$ c. $10^{6}$ bacteria in $10 \mu \mathrm{L}$.

The interaction between linolenic acid and serum was also studied by observing the clearing of an emulsion of $0.1 \%(\mathrm{v} / \mathrm{v})$ linolenic acid in pure agar around wells containing serum. The diameter of the zones of clearing followed closely those of neutralisation of the antibacterial activity of linolenic acid with different dilutions of serum (data not shown).

The nature of the linolenic neutralising capacity of serum has proved difficult to establish. The activity is not associated with purified human albumin or globulin, it is stable for $24 \mathrm{~h}$ at $56^{\circ} \mathrm{C}$ or $1 \mathrm{~h}$ at $100^{\circ} \mathrm{C}$, it is not extractable with chloroform, methanol or methanol/chloroform, suggesting that it is not a phospholipid or protein. It disappears during dialysis through a membrane (mol. wt $<125000$ ) and is not associated with calcium or magnesium ions because serum collected into containers with EDTA has unchanged activity. The effect of dilution of serum and a detergent (Triton X) or the inhibitory power of linolenic acid was similar. Thus, serum and Triton $\mathrm{X}$ cleared a linolenic-acid suspension to a similar extent as shown by the relationship between the log concentration of each substance and the size of the resultant zones. For both substances the relationship was not linear, with an unexpectedly large effect at low dilutions. This suggests that the linolenic-acid antagonism effect of serum may be due to "detergent" activity of a protein, polysaccharide or glycoprotein. Relevant to this was our finding that pooled serum, and serum from each of six healthy volunteers, inhibited the growth of four out of four (three coagulase-negative and one coagulase-positive) strains tested. The inhibition occurred optimally at a final dilution of $2 \%$ serum in nutrient agar and subinhibitory concentrations of linolenic acid reversed this inhibition. Thus serum and linolenic acid can be individually inhibitory, but a mixture loses this capacity.

\section{Effect of applied linolenic acid on the bactericidal activity of human skin}

In each of six volunteers, the application of neat linolenic acid to the skin caused a bactericidal effect on staphylococci subsequently inoculated (table V) 
TABLE V

Effect of addition of linolenic acid on the antibacterial properties of human skin

\begin{tabular}{c|cc}
\hline & \multicolumn{2}{|c}{$\begin{array}{c}\text { Percentage of inoculum* } \\
\text { recovered after } 6 \mathrm{~h} \text { from }\end{array}$} \\
\cline { 2 - 2 } $\begin{array}{c}\text { Subject } \\
\text { no. }\end{array}$ & $\begin{array}{c}\text { untreated } \\
\text { skin }\end{array}$ & $\begin{array}{c}\text { skin treated with } 10 \mu \mathrm{L} \\
\text { of linolenic acid }\end{array}$ \\
\hline 1 & 77.8 & $<0.01$ \\
2 & 56.6 & $<0.01$ \\
3 & 93.0 & $<0.01$ \\
4 & 8.4 & $<0.01$ \\
5 & 69.1 & 0.02 \\
6 & 73.5 & 0.16 \\
\hline
\end{tabular}

* Approximately $10^{6}$ cells of $S$. aureus strain 1030 in $10 \mu \mathrm{L}$ of serum.

and the bacteria that survived produced smaller-than-usual colonies of phagetyping pattern similar to that of the inoculated strain 1030. The destruction of the bacteria probably occurred on the skin surface because the recovery fluid contained $0.01 \mathrm{M}$ calcium chloride to inactivate any residual fatty acid. However, we cannot exclude the possibility that linolenic acid is taken up by bacteria on the skin surface, and its destructive effect occurs subsequently on nutrient agar.

\section{Attempts to select variants of $S$. aureus resistant to linolenic acid}

All the derivatives of strain 1030 containing plasmids or bacteriophages (Lacey 1980b) were tested for sensitivity to linolenic acid, and the MIC for each derivative was the same as for the wild strain. Heavy inocula $\left(\sim 10^{11}\right)$ of the pigmented cultures of strains 6936,609 and 1030 were then plated on medium containing increasing concentrations of linolenic acid and the plates were incubated for $72 \mathrm{~h}$. Each culture yielded (at a frequency of $\sim 10^{-9}$ ) some non-pigmented resistant variants at critical concentrations of fatty acid, usually $0 \cdot 05-0 \cdot 10 \%(\mathrm{v} / \mathrm{v})$. These variants grew slowly but on subculture reverted rapidly to normal-growing sensitive pigmented cells. Similar results were obtained after mutagenesis with nitrosoguanidine. Thus it was not possible to isolate stable variants of $S$. aureus resistant to linolenic acid.

\section{Sensitivity of other bacteria to linolenic acid}

Twenty-five strains of Escherichia coli, 25 Pseudomonas aeruginosa, 16 Proteus spp. and 25 Klebsiella spp. were all resistant to $0 \cdot 25 \%(\mathrm{v} / \mathrm{v})$ linolenic acid. Streptococci showed variable sensitivity with MICs from 0.01 to $0.025 \%$ for five of group A, $0.025 \%$ for three group B, $0.025 \%$ for two group C and $>0 \cdot 25 \%$ for nine strains of Streptococcus faecalis. 


\section{DisCUSSION}

Although there is uncertainty as to whether linolenic or linoleic acid is the fatty acid most inhibitory to bacteria in general, linolenic is shown here to be more inhibitory than linoleic acid to many strains of $S$. aureus. Sensitivity to linoleic acid is difficult to define because many cultures show a paradoxical effect whereby a high concentration is less inhibitory than a low one. Although sensitivity tests to linolenic acid separated the coagulase-positive staphylococci (sensitive) from the coagulase-negative strains (resistant), other unsaturated fatty acids showed little such effect.

Differences in sensitivity of staphylococci to linolenic acid in vitro may explain the variation in their survival on skin under the above experimental conditions. Cultures of $S$. aureus from animal sources survived less well on the skin than those from human material and the latter had a reduced survival compared with coagulase-negative strains. The poor survival of animal staphylococci on skin may be one of the factors explaining why there is apparently little parasitism of man by these bacteria.

Linolenic acid, although present in small quantities in the skin (Wilkinson, 1972) may well be an important naturally occurring antibacterial agent. Its presence could explain why pathogenic staphylococci are rarely found on intact skin. It will be interesting to examine individuals with a predisposition to recurrent skin sepsis, notably those suffering from diabetes mellitus, to determine whether there is a shortage of linolenic acid in their skin. Although $S$. aureus is rarely found on normal skin, patients with a variety of skin diseases are well known to harbour large numbers of pathogenic staphylococci. It is possible that the inhibitory property of linolenic acid is neutralised by serum, because most dermatoses are associated with a serous exudate. Similarly the skin around wounds created by surgical incision may be bathed in serum and might lose its natural antibacterial properties. In support of this postulated interaction between skin and serum in vivo, we have found that staphylococci applied to the skin surface suspended in serum survive better than those suspended in saline.

The nature of the interaction between linolenic acid and serum is not clear. Previously the only serum component known to react with free fatty acids is albumin (Spector, 1975); but albumin is not involved here because purified albumin has insignificant effect, and prolonged heating or extraction with organic solvents had no effect on the capacity of serum to inactivate linolenic acid. However, the neutralising capacity of the serum correlates with its ability to dissolve emulsions of linolenic acid in water, i.e., a "detergent" effect.

The addition of pure linolenic acid to the skin surface resulted in a dramatic enhancement of the bactericidal effect of the skin, even when the test bacteria were applied in serum. Presumably adequate free linolenic acid was still present. Pathogenic staphylococci and also cultures of Str. pyogenes are predictably sensitive to linolenic acid, although Enterobacteriaceae and Str. faecalis are resistant. Linolenic acid would, therefore, possess all the attributes of an ideal antibacterial agent and it could have specific indications, i.e., to 
control staphylococcal skin sepsis. It is naturally occurring and hence untoward reactions would be not anticipated, it should not destroy the commensal flora, resistance to it would not be expected to develop, and there would apparently be no risk of resistance to antibiotics developing during its use.

We thank Mrs Maureen de Saxe and Dr Vibeke Rosdahl for providing some of the strains of Staphylococcus aureus. We are grateful to the many volunteers who participated in these experiments.

\section{REFERENCES}

Aly, R., Maibach, H. I., Mandel, A. ANd Shinefield, H. R. 1976. Factors controlling the survival of Staphylococcus aureus on human skin. In Staphylococci and staphylococcal diseases. Proceedings of III International Symposium on Staphylococci and Staphylococcal Infections, Warszawa, 1975, edited by J. Jeljaszewicz, Fisher Verlag, Stuttgart, p. 941.

BAYLISS, M. 1936. Effect of the chemical constitution of soaps upon their germicidal properties. J. Bact., 31, 489.

ButcheR, G. W., KING, G. AND DyKe, K. G. H. 1976. Sensitivity of Staphylococcus aureus to unsaturated fatty acids. J. gen. Microbiol., 94, 290.

FULLER, R. AND MOORE, J. H. 1967. The inhibition of the growth of Clostridium welchii by lipids isolated from the contents of the small intestine of the pig. J. gen. Microbiol., 46, 23.

GutTeridge, J. M. C., LAMPORT, P. AND DoRmandy, T. L. 1976. The antibacterial effect of water-soluble compounds from autoxidising linolenic acid. J. med. Microbiol., 9, 105.

Heczko, P. B., Lutticken, R., Hryniewicz, W., Neugebauer, M. and Pulverer, G. 1979. Susceptibility of Staphylococcus aureus and group A, B, C, and G streptococci to free fatty acids. J. clin. Microbiol., 9, 333.

Kabara, J.J., Swieczkowski, D. M. Conley, A. J. and Truant, J. P. 1972. Fatty acids and derivatives as antimicrobial agents. Antimicrob. Agents Chemother., 2, 23.

KLOOS, W. E. AND SCHLEIFER, K. H. 1975. Simplified scheme for routine identification of human Staphylococcus species. J. clin. Microbiol., 1, 82.

Ko, H. L., Heczko, P. B. And Pulverer, G. 1978. Differential susceptibility of Propionibacterium acnes, Propionobacterium granulosum and Propionobacterium avidum to free fatty acids. J. invest. Dermat., 71, 363.

LACEY, R. W. 1968. Antibacterial action of human skin. In vivo effect of acetone, alcohol and soap on behaviour of Staphylococcus aureus. Br. J. exp. Path., 49, 209.

LACEY, R. W. 1980a. Rarity of gene transfer between animal and human isolates of Staphylococcus aureus in vitro. J. gen. Microbiol., 119, 437.

LACEY, R. W. 1980 $b$. Evidence for two mechanisms of plasmid transfer in mixed cultures of Staphylococcus aureus. J. gen. Microbiol., 119, 423.

Lacey, R. W., Lord, V. L., Gunasekera, H. K. W., Lieberman, P. J. and Luxton, D. E. A. 1980. Comparison of trimethoprim alone with trimethoprin-sulphamethoxazole in respiratory and urinary infections with particular reference to selection of trimethoprim resistance. Lancet, 1, 1270.

LACEY, R. W. AND STOKES, A. 1979. Studies on recently isolated cultures of methicillin-resistant Staphylococcus aureus. J. gen. Microbiol., 114, 329.

RiCKeTtS, C. R., SQUIRE, J. R. AND TOPLEY, E. 1951. Human skin lipids with particular reference to the self-sterilizing power of the skin. Clin. Sci., 10, 89.

SelwYN, S. AND Ellis, H. 1972. Skin bacteria and skin disinfection reconsidered. Br.med.J., 1, 136.

SPECTOR, A. A. 1975. Fatty acid binding to plasma albumin. J. lip. Res., 16, 165.

WILKINSON, D. I. 1972. Polyunsaturated fatty acids of skin; identification and ${ }^{14} \mathrm{C}$-acetate incorporation. Lipids, $7,544$. 